\title{
Citra Penjajahan Jepang di Indonesia yang Terpantul dalam Beberapa Novel Pramoedya ${ }^{1}$
}

\author{
Koh Young Hun
}

\begin{abstract}
Images of Japanese troops which drawn by Pramoedya in his works indeed related with his own experiences. Pramoedya through his characters portrays his view on humanities. Pramoedya depicted the brutality of Japanese troops in their occupation in Indonesia. All Japanese propaganda delivered false messages and caused disasters for Indonesian people. Japanese culture retardation and their brutality made the author suffer and down. Even though his novels associate with anti Japanese occupation and patriotism among the youth, humanities issues in fact appear as a strong theme in all his works.
\end{abstract}

KEYWORDS penjajahan, Jepang, Pramoedya, mysticum, pemberontakan, kemanusiaan

\section{KenyataAn DAN Karya Sastra}

Karya sastra dapat dilihat sebagai dokumen sosial budaya yang mencatat kenyataan di masyarakat pada suatu masa tertentu. Ia mencerminkan nilainilai seperti yang dimaksudkan oleh penulis. Oleh karena menggambarkan perasaan, harapan, dan aspirasi manusia, karya sastra menjadi pengukur yang mengesankan untuk melihat tindak-tanduk manusia terhadap tekanan sosial. Dalam pada itu, karya sastra perlu dilihat sebagai suatu keseluruhan. Kalau ia hanya tertarik pada unsur sosial budaya yang dilihat sebagai unsur yang dilepas dari kesatuan karya, dan hanya mendasar pada cerita tanpa mempersoalkan struktur karya, tidak ada perbedaan antara karya yang berdaya imajinasi tinggi dan rendah.

Karya sastra tidak dapat dilihat sebagai sarana yang mencerminkan realitas seperti cermin yang membalikkan citra objek yang terletak di depannya. Karya sastra adalah pengetahuan tentang realitas, dan pengetahuan ini bukanlah hal yang sama seperti membuat persamaan antara benda-benda di dalam dan di luar dunia dengan gagasan-gagasannya. Sebenarnya, realitas sudah terwujud di luar sebelum kita mengetahuinya dalam pikiran, tetapi realitas mempunyai bentuk (form), suatu bentuk yang disifatkan sebagai keseluruhan

$1 \quad$ Another version of this paper has been presented in The International Workshop on the People Experiences during the Japanese Occupation in Southeast and East Asia 1942-1945, The Faculty of Humanities University of Indonesia collaborates with The Toyota Foundation, Depok, Indonesia, 24-26 August 2005. 
dialektik dengan semua bagian yang berada dalam keadaan bergerak dan bertelingkah. Untuk memungkinkannya tercermin dalam karya sastra, realitas perlu disalurkan dalam karya penulis yang bersifat kreatif, yang memberikan bentuk. Karya yang terbentuk dengan betul dapat menghasilkan bentuk karya sastra yang mencerminkan bentuk dunia nyata.

Pramoedya merupakan salah seorang novelis yang mencerminkan kehidupannya dalam karya sastranya. Sebagian besar karya novelnya berlatar belakang pengalaman dirinya sendiri. Misalnya perselisihan keluarga yang berasal dari kemiskinan tercermin dalam Kemudian Lahirlah Dia (1950), suasana keluarga pada masa kecil dapat kita lihat dalam Yang Sudah Hilang (1950), keadaan dan suasana keluarga waktu ibunya meninggal muncul dalam Dia yang Menyerah (1950), pemberontakan Peta dan suasana menjelang kemerdekaan dapat dilihat dalam Perburuan (1950), pengalaman sebagai tentara digambarkan dalam Keranji Bekasi Jatuh (1947), pengalaman kecelakaan kereta api dilukiskan dalam Kemelut (1950), pengalaman pemenjaraannya di Bukit Duri dijelaskan dalam Mereka yang Dilumpuhkan (1951), dan suasana meninggalnya ayah Pramoedya diceritakan dalam Bukan Pasar Malam (1951).

Berbagai peristiwa yang terjadi pada tahun 1942 tidak dapat dilupakan Pramoedya dengan begitu saja karena pada tahun itu ia menghadapi beberapa kejadian yang amat mengejutkannya. Pada tanggal 2 Maret, tentara Jepang menduduki daerah Blora, kampung halamannya. Pasukan Jepang yang sudah mendarat di pantai utara Jawa akhirnya mencapai daerah Blora juga. Pada waktu itu, Pramoedya belajar di sekolah teknik radio di Surabaya. Dia menamatkan pendidikannya, tetapi tidak dapat menerima ijazahnya. Ijazah itu dikirim ke Bandung untuk disahkan dan tidak dikembalikan karena pada saat itu berakhirlah sejarah Hindia Timur Belanda yang diganti dengan pendudukan pasukan Jepang.

Saat ini merupakan masa yang penuh kesukaran bagi Pramoedya. Ayahnya yang kecewa akan gerakan nasionalis tidak pulang, ibunya jatuh sakit. Keadaan ini memaksa dia mencari nafkah hidup untuk keluarga besar, termasuk delapan orang adik. Pramoedya menjual rokok dan tembakau di Blora. Dia terpaksa naik sepeda ke Cepu untuk mencari dagangan rokok dan tembakau. Selain rokok dan tembakau, dia menjual benang tenun juga. Sesudah pulang kerja, dia merawat ibunya yang sakit. Namun, pada tahun itu juga, yaitu pada tanggal 3 Juni 1942 ibu yang disayanginya, Oemi Saidah, meninggal dunia dalam usia 34 tahun karena penyakit TBC. Keesokan harinya adik bungsunya Soesanti yang baru berumur tujuh bulan meninggal dunia juga. Kematian saudaranya ini membuat Pramoedya sedih sekali. Khususnya kematian ibunya bagi dia merupakan kehilangan yang paling menyedihkan. Neneknya, Mbah Sabarijah didatangkan dari Ngadiluwih untuk mengurus keluarga, namun tidak lama ia tinggal di Blora. Kemudian, adiknya Oemisafatoen yang baru berumur 12 tahun mendapat tugas mengurus rumah tangga. Kakak perempuannya Koenmarjatoen yang dua tahun lebih tua, dibebaskan dari tugas itu, dan sempat meneruskan pendidikan sebagai 
juru tik. Situasi ini antara lain dijadikan motif cerita Dia yang Menyerah, di dalamnya dapat dilihat suasana pendudukan pasukan Jepang juga.

Pengalaman dengan orang di sekitarnya pada waktu ibunya meninggal dan segala sesuatu yang terjadi sesudahnya menjadikan Pramoedya kehilangan kepercayaan pada sesama manusia, dan ia tidak betah lagi di Blora. Ia berangkat ke Jakarta dengan adiknya Prawito yang kemudian berganti nama menjadi Waloejadi. Ia mendaftar pada lembaga pendidikan Taman Siswa yang diakui oleh pemerintah Jepang. Di sekolah ini ia belajar bahasa Indonesia dari Mara Sutan. Pramoedya menganggap bahasa Indonesia pada zaman itu sebagai bukan sekadar mata pelajaran, melainkan juga sebagai sarana untuk memupuk semangat kesadaran bangsa pada para muridnya. ${ }^{2}$ Dan ia memanfaatkan setiap kemungkinan untuk membaca apa saja yang dapat diperoleh: sastra, filsafat, sejarah.

Pada sore dan malam hari Pramoedya bekerja di kantor berita Domei sebagai juru tik. Sepertiga gajinya, yang sebesar 35 rupiah, dikirim kepada adik perempuannya di Blora yang memelihara adik-adiknya yang lain. Ia tidak belajar lama di Taman Siswa karena Jepang membubarkan sekolah itu pada Agustus 1943 ketika dia naik ke kelas tiga. Maka, perhatiannya sejak itu diberikan kepada buku sastra yang dibeli atau disewanya.

Pramoedya mendapat kesempatan lagi untuk melanjutkan pendidikannya pada bulan Februari 1944, ketika pihak Domei mengadakan pemilihan antara para pegawainya yang lulusan sekolah menengah untuk calon pelajar di sekolah stenografi Tjuo Sangi-in (中央參議院). Pramoedya terpilih menjadi murid dan belajar selama satu tahun di sana. ${ }^{3}$ Ketika itu, Pramoedya sempat berkenalan dengan beberapa tokoh politis di samping memperkokoh minat pada sastra. Ia tamat kursus itu pada bulan Maret 1945. Pramoedya berkesempatan belajar juga di Sekolah Tinggi Islam di Gondangdia. Pada tahun itu, ia bekerja kembali di Domei, yaitu di bagian khusus perkembangan perang Cina-Jepang. Sementara itu, Pramoedya mulai bertentangan dengan pimpinannya, orang Jepang, karena adanya perlakuan diskriminatif. ${ }^{4}$ Akhirnya, pada bulan Juni 1945 Pramoedya, meninggalkan Jakarta untuk menjelajah: Jawa Tengah dan Jawa Timur untuk beberapa lama.

Ketika Pramoedya bermukim sejenak di Kediri pada bulan Agustus 1945, ia mendengar berita kemerdekaan Indonesia dari bekas anggota Peta. Pramoedya segera menuju ke Surabaya dan kemudian kembali ke Jakarta setelah singgah sebentar di Blora. Di Blora ia sempat menyaksikan teater yang

\footnotetext{
$2 \quad$ Pramoedya cepat menyesuaikan bahasa Indonesianya, yang pada awalnya kejawajawaan, dengan logat Melayu. Dia mulai merasa sebagai orang Indonesia sepenuhnya, bukan lagi orang Jawa dengan etiket Indonesia (Lihat Teeuw, 1997, Citra Manusia Indonesia dalam Karya Sastra Pramoedya Ananta Toer, hlm. 17).

3 Gurunya antara lain Karundeng (stenografi), Raihul Amar (bahasa Indonesia), Mohamad Hatta (ekonomi), Maruto Nitimihardjo (sosiologi), Sukardjo Wirjopranoto (politik).

4 Pihak Domei menyekolahkan dua orang termasuk Pramoedya dalam kursus stenografi. Mereka berdua lulus dengan cemerlang. Namun, ketika kembali bekerja di kantor berita tersebut, teman Pramoedya ini langsung mendapat promosi jadi anggota staf redaksi, sedangkan Pramoedya hanya menjadi asisten di bagian arsip.
} 
berjudul Indonesia Merdeka. Namun, Pramoedya tidak puas hati karena teater yang menggambarkan semangat anti-Jepang dan patriotik itu kurang baik mutunya. Oleh karena itu, ia merencanakan untuk menulis cerita yang jauh lebih baik daripada Indonesia Merdeka. Kemudian, dia menulis Perburuan, di penjara Bukit Duri, yang berisikan anti-Jepang dan patriotisme.

Pengalaman Pramoedya selama masa penjajahan Jepang tidak pernah langsung dijadikan pokok karya sastra. Namun, masa itu dimanfaatkannya sebagai latar beberapa novel: dalam Perburuan, perjuangan bawah tanah gerilyawan Peta melawan penjajah menjadi garis utama plotnya; dan dalam Dia yang Menyerah penderitaan penduduk Jawa selama periode itu juga mendapat tempat yang selayaknya dalam cerita yang secara khas juga membayangkan keluarga yang mirip dengan keluarganya sendiri di Blora (Teeuw 1997: 19).

Perlu dijelaskan lagi bahwa pengalaman seorang novelis dapat langsung dicerminkan dalam karya sastranya. Dalam konteks ini, dapat dikatakan bahwa citra dan kesan tentang pasukan Jepang yang dipaparkan dalam novel Perburuan sebenarnya berhubungkaitan juga dengan pengalaman Pramoedya sendiri. Pramoedya menguraikan hubungan karya sastra dengan aspek luarnya dengan menggunakan istilah kenyataan hulu dan hilir. Menurutnya, kenyataan adalah kebenaran hulu. Dalam tanggapan pengarang ia menjadi kenyataan atau kebenaran hilir yang terolah dengan sejumlah kekayaan dan kebatinan si pengarang, dan tentu saja tak dapat dilupakan, daya imajinasi. Membaca sastra tak lain dari membaca kebenaran hilir, kemampuan batin, dan daya imajinasi pengarangnya (Toer, ed. 1987: xxvi). Dengan perkataan lain, dalam pengaryaan Pramoedya hampir selalu terdapat kaitan dengan kenyataan hulu yang konkret: peristiwa tertentu yang dialaminya, tokohtokoh yang pernah ditemuinya, kejadian yang didengarkannya, dan terutama dalam roman dan cerita sesudah 1956 fakta sejarah yang digalinya dari berbagai macam sumber. Maka, tak heran pula bagi Pramoedya kaitan antara kenyataan hulu dan hilir, walaupun keduanya berbeda secara prinsip, harus ada pada penulisan yang baik (Teeuw 1995: 7).

Berhubungan dengan itu, Pramoedya juga menguraikan proses dunia pengaryaannya sebagai proses yang semata-mata bersifat individual, yang dapat terjadi hanya setelah terbentuk mysticum. Keadaan mysticum bagi Pramoedya adalah kebebasan pribadi yang padat, yang melepaskan pribadi dari dunia luarnya, yang menyebabkan pribadi tidak terjamah oleh kekuasaan waktu. Dalam kondisi itu, yang ada hanya sang pribadi dalam hubungan antara kawula dan gusti dengan bukti kegustiannya, tertampillah sang kreator dengan Kreator melalui pernyataan-pernyataannya (Toer 1983: 28). Pengalaman mistik ini dikemukakan dalam hubungan dengan penciptaan Perburuan yang datang sebagai semacam pencerahan dan pembebasan dalam krisis kejiwaan yang sangat parah. Waktu Pramoedya berada dalam tahanan Belanda, memang ia sengaja hendak bunuh diri dengan patiraga, pesangon dari ibunya sebelum pergi ke alam baka, yang hanya boleh dipergunakan pada waktu krisis jiwa yang tidak dapat diatasinya. Penemuan mysticum 
dalam proses penciptaan Perburuan membebaskannya dari krisis itu (Toer 1983: 28).

\section{Semangat Anti-Jepang, Patriotisme Pemuda, dan Pengorbanan DIRINYA SENDIRI}

Pramoedya menghasilkan Perburuan pada bulan Mei 1949 dalam penjara Bukit Duri. Cerita ini diilhami oleh pemberontakan pasukan Peta di bawah pimpinan Supriyadi terhadap Jepang di Blitar, Kediri, Jawa Timur pada tanggal 14 sampai dengan 15 Februari 1945, enam bulan sebelum Indonesia merdeka. ${ }^{5}$ Pemberontakan pasukan Peta ini memberi kesan yang luar biasa kepada Pramoedya yang menyimpan inferiority complex terhadap sejarah bangsanya sendiri. Anderson (1961: 47) menyifatkan pemberontakan ini sebagai serangan tunggal yang paling serius pada kuasa Jepang selama penjajahan.

Novel ini melukiskan nasib dan situasi tujuh orang, yang bertaut penghidupannya sejak senja 16 Agustus sampai dengan waktu lohor 17 Agustus, hari proklamasi kemerdekaan Indonesia. Tokoh utama Hardo digambarkan sebagai shodanco (小團長) pasukan Peta yang merencanakan pemberontakan terhadap Jepang bersama Dipo dan Karmin, didorong oleh semangat patriotisme. Tujuannya adalah turut mempercepat proses keruntuhan Jepang di Indonesia umumnya, dan di daerah Blora khususnya. Namun, rencana pemberontakan ini gagal karena Karmin mengkhianatinya dan melaporkan rencana itu kepada penjajah Jepang. Oleh karena itu, Hardo dan Dipo diburu-buru oleh tentara Jepang. Gara-gara kegagalan rencana pemberontakan ini, ayah Hardo akhirnya dipecat dari jabatan Wedana Karangjati oleh Jepang. Malah ibu Hardo juga meninggal dunia karena terpukul dan sakit setelah diperintah Jepang untuk ikut mengepung anak kandungnya sendiri.

Di sini Pramoedya mengemukakan masalahnya melalui beberapa orang tokoh, termasuk masalah kemanusiaan yang paling menonjol dalam novel ini. Walaupun novel ini berlatar belakang zaman penjajahan Jepang, dan tampaknya semangat anti-Jepang dan patriotisme pemuda terhadap tanah airnya itu menonjol, benang merah yang dapat menghubungkaitkan pemikiran Pramoedya dalam karya ini adalah tidak lain dari kemanusiaan. Pada bagian akhir novel ini Hardo menunjukkan sikap toleran pada Karmin yang mengkhianatinya. Hardolah yang mencegah Dipo dan teman-temannya yang bersenjata bambu runcing ketika hendak menyerang Karmin. Teeuw

$5 \quad$ Peta dibentuk pada awal bulan Oktober 1943. Meskipun Peta berada di bawah pengawasan Jepang, dan meskipun persenjataannya berada di bawah kontrol ketat Jepang, para perwira Indonesia dan pimpinannya dipilih dari para intelektual Indonesia yang bersemangat nasional. Dalam perkembangannya ternyata tentara Peta di beberapa Daidan anggotanya merasa kecewa akan Jepang. Kekecewaan di kalangan Peta, terutama para perwira juga timbul terhadap para bintara dan tamtama Jepang. Mereka merasa bahwa status mereka direndahkan terhadap prajurit Jepang yang berpangkat bukan perwira. Kekecewaan mereka sudah dimulai dalam tahun 1944, bahkan menimbulkan beberapa pemberontakan. Di antaranya yang terbesar adalah pemberontakan Peta Blitar pada tanggal 14 Februai 1945, yang dipimpin oleh Supriadi dan Moeradi. 
juga berpendapat bahwa Hardo mengetahui Karmin tidak mengambil pilihan yang salah pada dasarnya, dan bahwa teman-temannya harus membantunya melawan kelemahan kemanusiaannya. Sesungguhnya pada akhir buku ini Hardo menyelamatkan nyawa Karmin (Teeuw 1980: 232-233). Kesalahan Karmin bagi Hardo tidak merupakan alasan untuk menjadi marah dan menyalahkannya, melainkan untuk menyayangkan ketololannya dengan sikap toleran, yang berasal dari kemanusiaan. Sikap Hardo ini dapat dilihat dalam beberapa bagian dalam novel ini.

Dan engkau, Karmin-engkau harus kembali padaku, Tidak-aku takkan membalas dendam oleh pengkhianatan itu (Toer 2001: 10).

Anggaplah dia sebagai orang sakit, Dipo! Dan karena itu segala tindakannya adalah tindakan sakit. Dan karena tindakan sakit maka engkau tak boleh menghukum atau membencinya (65).

Hakikat ini menunjukkan bahwa Pramoedya menaruh harapan pada semua jenis lapisan orang walaupun dia melakukan perbuatan yang jahat dan berkhianat. Ini disebabkan oleh kemampuan Pramoedya meninjau dari pelbagai aspek. Ia menganggap bahwa nilai kemanusiaan tetap ada pada manusia yang jahat sekalipun. Bahrum Rangkuti juga berpendapat bahwa Pramoedya tidak menghukum, apalagi meremukkan seseorang, bagaimanapun buruknya tingkah laku atau sifat orang itu (Rangkuti 1963: 106). Baginya, manusia adalah suatu kewujudan yang menyeluruh; tindakannya bersifat baik atau jahat hanyalah merupakan sebagian dari keseluruhan itu.

Tindakan pihak penjajah Jepang yang tidak berperikemanusiaan membuat Pramoedya terpukul. Dibandingkan dengan penguasa asing yang mendatangi kepulauan Indonesia dengan membawa agama atau barang dagangan, pihak Jepang mengeksploitasi negeri jajahannya sebagai pangkalan persiapan Perang Dunia Kedua. ${ }^{6}$ Oleh karena itu, penganiayaan pihak Jepang terhadap orang Indonesia jauh lebih serius daripada penguasa asing yang lain. Pasukan Jepang mendarat di Indonesia dengan semboyan "Lingkungan Kemakmuran Bersama Asia Timur Raya". Selain di Indonesia, di negeri yang dikuasai, Jepang mencoba mengelabuhi rakyat dengan propaganda tersebut dan membangkitkan kebencian terhadap bangsa-bangsa penjajah kulit putih. Namun, walaupun propagandanya gencar, jutaan manusia di negeri-negeri itu mati secara menyedihkan, baik karena perang dan kelaparan, maupun akibat siksaan tentara Jepang. Dari negeri-negeri yang diduduki itu Jepang mengeruk banyak kekayaan dengan alasan untuk kepentingan perang, demi semboyan "Lingkungan Kemakmuran Bersama Asia Timur Raya”.

6 Pada tanggal 8 Desember secara tiba-tiba Jepang menyerbu ke Asia Tenggara dan mengebom Pearl Harbor. Setelah sukses menduduki Malaysia dan Filipina, Jepang menyerbu juga Indonesia (Hindia Belanda) sebagai gerakannya ke selatan. Pada tanggal 11 Januari 1942 tentaranya telah mendarat di Tarakan, Kalimantan Timur, dan keesokan harinya Komandan Belanda di pulau itu menyerah. Tidak lama kemudian, pada tanggal 24 Januari 1942, Balikpapan yang merupakan sumber minyak kedua jatuh ke tangan tentara Jepang. Mereka masuk ke Jawa pada tanggal 1 Maret 1942 di Teluk Banten dan Kragan. 
Menurut Pramoedya, orang Jepang yang melaksanakan tugasnya tidak segan-segan mendemonstrasikan kekejaman, kekejian, kerakusan, dan kekerasan yang sungguh-sungguh memuakkan. Dia sendiri berkalikali menyaksikan keterbelakangan budaya dan peradaban ini sejak mereka mendarat di Jawa pada 1 Maret 1942 (Toer 2001: 9). Pramoedya menggambarkan citra pasukan Jepang yang negatif ini dalam novel Perburuan. Kekejaman tentara Jepang dilukiskan Pramoedya seperti berikut:

Samurai Nippon itu bisa menceraikan kepala dari lehernya. Kalau suatu kali kudengar dia mati di pinggir jalan dimakan belatung ... Alangkah akan puas rasa hatiku (Toer 1950: 11)

Sebagaimana dijelaskan di atas, pengalaman Pramoedya pada waktu pendudukan pasukan Jepang jauh berbeda dari penguasa asing yang lain. Pramoedya sendiri menyaksikan penganiayaan tentara Jepang terhadap rakyat Indonesia, antara lain, merogol perempuan, merampas harta benda. Mereka mengerahkan gadis-gadis dan menjadikannya mangsa seksual untuk serdadunya, sebagaimana yang dilaksanakan di Korea oleh penjajah Jepang. Pramoedya berpendapat bahwa kesulitan hubungan laut dan udara menyebabkan bala tentara Jepang tidak lagi mampu mendatangkan wanita penghibur dari Jepang, Cina, dan Korea. Sebagai gantinya, gadis Indonesia dikirimkan ke garis terdepan sebagai penghibur (Toer 2001: 2). Pada mulanya para remaja betul-betul tertarik, bersemangat, bergairah karena yang dipropagandakan pemerintah Jepang sesuai dengan harapan mereka. Ternyata mereka ditipu Jepang yang menjanjikan akan menyekolahkan mereka ke Jepang. Ternyata mereka dibawa ke garis depan untuk dijadikan pelacur guna melayani serdadu Jepang. Sebenarnya pihak Jepang merencanakan koreanisasinya Indonesia. Ini bermaksud bahwa cara-cara efisien untuk menjajah Indonesia diambil dari pengalaman penjajahan mereka di Korea yang berlangsung selama lebih dari 30 tahun, pada waktu itu. Pramoedya menguraikannya seperti berikut.

At first Jakarta felt calm, safe, and pleasant, but as time passed I became more and more convinced that no place under the control of Japanese militarism was any longer safe ... torture, often to death, of people accused of quite minor offenses; a large-scale massacre of everyone with an elementary education on up, in West Borneo, to permit the region "Koreanization." ... The thought, of course, occurred to me: what kind of people are they really? Their behavior doesn't simply aroused hatred - but utter loathing ... Such cruelties and brutalities thus became, for the first time in my life, part of the data accumulated within myself, and they often surface in my consciousness to this very day. The power of time has proved incapable of erasing them (Toer 1983: 30-32).

Kalau Jepang hanya hendak menggantikan imperialis Barat di Asia Tenggara, khususnya di Indonesia, dan tingkat peradabannya setara dengan Belanda, barangkali masyarakat Indonesia tidak menyangsikan pendudukan pasukan Jepang. Akan tetapi, watak fasis-militeris Jepang telah menyebarkan penderitaan berlebihan di setiap jengkal tanah. Teror merupakan sistem untuk 
menundukkan rakyat, sedangkan kerakusan berlebihan menjadi tujuan dari pendudukan itu (Toer 2001: 22).

Walaupun Pramoedya pernah bekerja di kantor berita Jepang Domei, kekecewaan akan penjajah Jepang amatlah besar. Kekecewaan dan kebenciannya terbayang melalui tokoh-tokoh yang muncul dalam novel Perburuan. Ketika Hardo bertemu dengan ayahnya di dalam gubuk yang terletak di ladang jagung, dia kesal sekali ketika mengetahui ibunya meninggal karena bersusah hati. Pihak Jepang mengerahkan rakyat untuk mengepung Hardo dan ibunya. Gara-gara ancaman pihak Jepang yang biadab ini, ibunya jatuh sakit, dan akhirnya meninggal dunia. Selain itu, sindiran kebencian terhadap pasukan Jepang dipaparkan juga dalam dialog antara Hardo dan ayahnya seperti berikut.

Mereka membangunkan perasaan hormat pada diri sendiri sambil menunjukkan kebiadaban musuhnya. Tapi Nippon dengan tiada disadarinya membuat liang kuburnya sendiri. Dikiranya orang Indonesia tak ada melihat sesuatu keburukan dan kehinaan pada badannya. Hmm, orang Indonesia sadar juga akan keganasan gurunya (Toer 1983: 39)

Novel Perburuan sebenarnya didorong sepenuhnya oleh semangat antimiliterisme Jepang dan sebagai timbangannya semangat patriotik. Berdasarkan pengalamannya sendiri pada masa itu dan cerita yang didengarnya tentang kekejian dan keganasan masa itu yang baru pertama kali masuk sebagai data dalam dirinya, Pramoedya menggugah perasaan benci, muak, jijik yang demikian intensif sehingga kekuasaan sang waktu tidak mampu menghapuskannya (Teeuw 1995: 8).

Cerita Dia yang Menyerah lebih memfokuskan pada pengorbanan tokoh utamanya, yaitu Sri yang umurnya, pada awal cerita, baru sebelas tahun. Pramoedya menceritakan berbagai peristiwa menyedihkan yang dialami Sri dan keluarganya selama periode yang penuh guncangan, mulai dari pendaratan pasukan Jepang di Jawa sampai kemerdekaan. Teeuw juga menjelaskan bahwa cerita ini melingkupi periode yang panjang, dan urutan waktu ditandai dengan jelas. Latar historis dapat dikenali dengan tepat, selama periode yang lebih dari delapan tahun, dan peristiwa-peristiwa sejarah itu mempunyai dampak yang menentukan pada pengalaman Sri sekeluarga (Teeuw 1997: 120). Dalam cerita ini dapat disaksikan keruntuhan suatu keluarga sebagai objek dan korban urutan peristiwa sejarah. Namun, keruntuhan ini tidak total sebab dua gadis Sri dan Diah berhasil mempertahankan normanya di tengah dan sepanjang segala musibah dan kesengsaraan, dengan satu-satunya senjata yang tinggal: menerima, menyerah. Dalam konteks Jawa menyerah bukanlah tanda kelemahan moral atau ketakutan. Menyerah adalah cara untuk bertahan hidup tanpa meninggalkan prinsip moral atau kemanusiaan (Teeuw 1995: 14).

Tokoh utama Sri merupakan salah seorang korban yang harus menahan dan menerima penderitaan seluruh keluarga. Dia yang harus mengurus rumah tangga. Kakaknya Is mengeksploitasi hak istimewanya sebagai kakak. Sri terus-menerus terpaksa menyerah dan mengalah. Sri terpaksa meninggalkan 
niatnya untuk belajar terus, padahal tinggal dua bulan lagi lulus. Penderitaan Sri dapat dikatakan lambang ribuan keluarga lain sebagai korban dalam kejadian politis selama bertahun-tahun, yang demikian kuat dampaknya pada sejarah Indonesia. Dapat dikatakan bahwa keluarga Sri pada awal cerita menjadi sengsara karena penjajahan pasukan Jepang. Dalam pada itu, Pramoedya menunjukkan ketidakbetahannya melihat masuknya pasukan Jepang di daerah seperti berikut.

Jepang tak melupakan kampung-kampung yang sering dilupakan oleh ilmu bumi. Dan karena kampung kami terletak di kota kecil yang merupakan suatu terusan yang menghubungkan pantai Rembang-Lasem dengan daerah pedalaman yang penting, maka pasukan Jepang pun menusuk kota kami-kampung kami yang damai itu (Toer 2001: 224)

Pada awal cerita ini masyarakat Indonesia menyambut baik kedatangan pasukan Jepang. Akan tetapi, kalau dikatakan dengan tepat, mereka ditipu oleh propaganda Jepang. Ayah Sri juga, yang bergairah menanggapi pendudukan Jepang, mulai belajar bahasa Jepang dan menceburkan diri dalam berbagai amal sosial demi pendidikan rakyat. Pramoedya memaparkannya, "Pendaratan balatentara Dai Nippon membuat lapisan muda jadi dinamis. Mereka mengagumi Jepang. Dan Jepang telah meruntuhkan seluruh kebesaran dunia kulit putih di daratan Asia dan pulau-pulaunya." (226); "Sebagai seorang yang berdarah panas, haus akan perbaikan masyarakat, benci pada penjajahan Belanda dan belum sadar akan kejahatan penjajahan Jepang, bapak mereka terlampau simpati pada penjajah baru yang berpanji-panji kemakmuran bersama itu." (230). Namun, semangat ayah Sri segera sirna ketika menerima berita bahwa kedua anak tertua yang disayanginya gugur sebagai sakura di medan perang Birma. Sri juga merasa kesal karena "surat gadai dua belas lembar yang tertebus dan jadi tak berharga oleh penyerbuan balatentara Dai Nippon." (227).

\section{KESIMPULAN}

Walaupun topik utamanya tidak bertujuan untuk menambah kesan negatif tentang pendudukan pasukan Jepang, Pramoedya memaparkan juga kesankesan yang buruk tentang pasukan penjajahan Jepang dalam novel Perburuan, dan Dia yang Menyerah. Pramoedya tidak gagal menunjukkan betapa kejamnya Jepang waktu mereka menjajah Indonesia. Segala propaganda Jepang yang kosong sebenarnya mengakibatkan bencana yang menyedihkan bagi rakyat Indonesia. Keterbelakangan budaya dan kebiadaban Jepang membuat Pramoedya terpukul dan menderita.

Tidak dapat dinafikan bahwa Jepang pernah menganiaya negeri-negeri tetangga untuk kepentingan dirinya. Tidak masuk akal juga seandainya ada yang berpendapat bahwa kekuasaan kolonial Jepang bermanfaat bagi modernisasi setiap negeri yang pernah dijajah olehnya. Dalam pada itu, pihak Jepang perlu mengakui kesalahan mereka pada waktu menjajah negeri tetangga, dan meminta maaf dengan sungguh-sungguh. Dewasa 
ini sebagian masyarakat Jepang, khususnya golongan sayap kanan yang fanatik, berkecenderungan memutarbalikkan fakta sejarah yang berkenaan dengan penjajahan mereka di Asia Timur dan Asia Tenggara dalam buku teks mereka sendiri. Selain itu, ada yang mengatakan kemungkinan muncul kembali militerisme Jepang. Gejala seperti ini sebenarnya dapat menghambat penjalinan hubungan diplomatis Jepang dengan negeri-negeri yang pernah dijajah, dan dapat mengancam ketertiban dunia yang waras. Dalam konteks ini, kemungkinan besar ada peranan penting dari kalangan sastrawan dan budayawan setempat untuk memperbaiki penjungkirbalikan fakta sejarah yang berkaitan dengan pendudukan Jepang di setiap negeri.

\section{DAFTAR ACUAN}

Anderson, Benedict (1961), Some Aspects of Indonesian Politics under the Japanese Occupation: 1944-1945. Ithaca: Cornell University Press.

Koh Young Hun (1996), Pemikiran Pramoedya Ananta Toer dalam Novel-Novel Mutakhirnya. Kuala Lumpur: Dewan Bahasa dan Pustaka.

Luckas, Georg (1971), The Theory of the Novel. Massachusetts: The MIT Press.

Poesponegoro, Marwati Djoened, Nugroho Notosusanto (1990), Sejarah Nasional Indonesia. Jakarta: Balai Pustaka.

Rangkuti, Bahrum (1963), Pramoedya Ananta Toer dan Karya Seninya. Jakarta: Gunung Agung. Toer, Pramoedya Ananta (2001), Cerita dari Blora. Jakarta: Hasta Mitra.

Toer, Pramoedya Ananta (2001), Perawan Remaja dalam Cengkeraman Militer. Jakarta: KPG.

Toer, Pramoedya Ananta (1983), "Perburuan 1950 and Keluarga Gerilya 1950" dalam Indonesia No. 46. Ithaca: Cornell University. pp.25-48.

Toer, Pramoedya Ananta (1950), Perburuan. Jakarta: Balai Pustaka.

Teeuw, A. (1997), Citra Manusia Indonesia dalam Karya Sastra Pramoedya Ananta Toer. Jakarta: Pustaka Jaya.

Teeuw, A. (1995), “Revolusi Indonesia dalam Imajinasi Pramoedya Ananta Toer” dalam Jurnal Kalam No. 6. pp. 4-47.

Teeuw, A. (1978), Sastra Baru Indonesia. Ende: Nusa indah 